\title{
A Portrait of the Animal as a Young Artist: Animality, Instinct, and Cognition in Joyce's Early Prose
}

\author{
John S. Rickard \\ Department of English, Bucknell University, Lewisburg, PA 17837, USA; rickard@bucknell.edu \\ Received: 2 June 2017; Accepted: 31 July 2017; Published: 3 August 2017
}

\begin{abstract}
This essay situates James Joyce within the competing discourses of Catholic theology, evolutionary biology, and Nietzsche's philosophy, with emphasis on their attitudes towards the body and the animal-human boundary. Joyce's use of "instinct" in his early works (Dubliners, Stephen Hero, and $A$ Portrait of the Artist as a Young Man) helps us understand his movement from a view of animals and the human body as frightening or paralyzing to a more open acceptance of the body and its impulses. This transition from portraying the body as an impediment in Dubliners to a source of knowledge or cognition in A Portrait of the Artist as a Young Man helps us better understand Joyce's early prose and his embrace of both animal and human bodies in his later works.
\end{abstract}

Keywords: James Joyce; instinct; animals; body; evolution; cognition

\begin{abstract}
"By the late twentieth century in United States scientific culture, the boundary between human and animal is thoroughly breached. The last beachheads of uniqueness have been polluted if not turned into amusement parks—language, tool use, social behaviour, mental events, nothing really convincingly settles the separation of human and animal." Donna Haraway, “A Cyborg Manifesto” (Haraway 1991, p. 151)
\end{abstract}

If, as Donna Haraway has argued, "the boundary between human and animal" was "thoroughly breached" in the twentieth century, James Joyce was surely one of the early instigators of this breach in early twentieth century literature. Much recent scholarship has examined the animal-human boundary lines in Joyce's prose. In "Ulysses: Changing into an Animal," Maud Ellmann claims that "throughout Ulysses, machines and animals encroach upon the heroes' consciousness, fraying the edges of the human universe" (Ellmann 2006, p. 76). In "Heavenbeast: A New Materialist Approach to Ulysses," Donovan Schaefer has argued that "Ulysses might be called a piece of animal literature-a book that always leads to sex, deviation, desire, excess, and defilement, moments where the sovereignty of the human self over the body is blurred" (Schaefer 2016, p. 134). In a discussion of "Bodies" in Ulysses, Vike Martina Plock notes that "With a view to challenging anthropocentric viewpoints, Joyce also reserves space for the representation of bodies belonging to non-human species," concluding that "animals are at the forefront of the novel's conceptual agenda" (Plock 2014, p. 193). David Rando has examined animals and "the veterinary gaze" in Ulysses (Rando 2009), and Margot Norris, among others, has extended this investigation of "the status of the animal as a signifier" into Finnegans Wake, maintaining that "The animals in Finnegans Wake merit further attention not only for their numerous appearances in wordplay, puns, and allusions, but also for their thematic roles as figures, characters, and signifiers, all of which serve to enhance and deepen the ecological vision of this 1939 dream-work" (Norris 2014, pp. 527-28).

While Joyce's later works have captured most of the attention of critics looking at his textual menagerie, some authors have turned their "veterinary gazes" on Joyce's early fictions. In his dissertation "James Joyce's Animal Aesthetic," Michael Nunn notes that "One remarkable feature 
of Portrait is its teeming animal life..." (Nunn 2009, p. 101), and Maureen O'Connor pays particular attention to A Portrait of the Artist as a Young Man, as well as to Ulysses, in her study of "human/animal transformations in Joyce's fiction" (O'Connor 2013, p. 102). This essay will engage these and other recent discussions of "the animal" and embodiment in Joyce's early prose works by using "instinct" as a key word that illuminates the evolution of Joyce's view of the human body as a source of knowledge or cognition rather than as a "brute," animal, unthinking material substance that threatens or degrades the "soul." By using "instinct" as a focus, I hope to historicize Joyce's position within contemporary debates about the body, animality, will, and cognition in turn of the century Ireland. By closely examining the way Joyce works "instinct" into Dubliners, Stephen Hero, and A Portrait, we can see a development in his portrayal of what we might call "the human animal" - the portrayal of human beings as embodied animals, rather than as souls temporarily housed in bodies.

We can place the young James Joyce historically into late nineteenth and early twentieth century debates about the relationship between human and animal by examining the tensions between Darwinian ideas that view the human being as part of a continuum of animal life versus Roman Catholic attempts to assert older paradigms that maintain a definite, spiritual boundary between the animal and the human. When he was writing Ulysses, Joyce told his friend Frank Budgen, "my book is the epic of the human body ... In my book the body lives in and moves through space and is the home of a full human personality. The words I write are adapted to express first one of its functions then another ... " Budgen objected, "But the minds, the thoughts of the characters," and Joyce responded, "If they had no body they would have no mind" (Budgen 1972, p. 21). By interrogating Joyce's earlier fiction, we can seek the early manifestations of his embrace of instinct and sexuality and his radical vision of the human body as an animal body freed from the binary opposition of "body" and "soul."

Joyce was of course familiar with the outlines of Darwin's thought, as any young intellectual of his time would have been. As I and others have noted, Joyce clearly refers to Darwin in his novels, most notably in Ulysses but also in A Portrait of the Artist as a Young Man. ${ }^{1}$ His familiarity with authors writing in Darwin's wake — especially Friedrich Nietzsche-would have challenged the prevailing Roman Catholic notion of the human as fundamentally separate from the "brute" animal, as presented by Thomas Aquinas and other Catholic theologians and presented to him, I will argue below, most clearly in Michael Maher's Psychology (Maher n.d.), part of the Manuals of Catholic Philosophy series. As usual, Joyce made fruitful use of the contradictions or creative tensions he found in his environment, and by reading his early prose fictions within the matrix created by this cultural crisis, we can get a better sense of how he used his writing to develop his thinking about the human body, the "animal," and the soul.

This contrast between competing discourses and their representations of the human-animal boundary line is complex and nuanced, and I do not mean to suggest that Joyce moved in any simple or clear way from a Catholic view to a Darwinian perspective. Nonetheless, I believe we can read Dubliners, Stephen Hero, and A Portrait as creative responses to this tension Joyce clearly encountered in his reading and education. In this I follow Umberto Eco's sense that we can approach works of art as "epistemological metaphors" that reflect a "chaosmos" (borrowing a neologism from Finnegans Wake) formed on the fault lines between older and modern epistemes (Eco 1982, p. vii). In Joyce's early prose, the Catholic idea of the soul remains in tension with the growing sense that the liberation of the human being requires an embrace of our animal nature, represented by the body and by instinct.

The young Joyce at times reacted with bitterness to what he viewed as the repressive view of the body presented in his Catholic education. In 1904, Joyce wrote in a letter to Nora Barnacle, "Six years ago I left the Catholic Church, hating it most fervently. I found it impossible for me to remain

1 For a brief discussion of Joyce's references to Darwin and related reading in evolutionary theory see Rickard (Rickard 1998, pp. 119-21). 
in it on account of the impulses of my nature ... Now I make open war upon it by what I write and say and do" (Joyce 1957-1966, II, p. 48). As Richard Brown has written, "The Church system failed, in [Joyce's] view, in that it did not recognize his full biological humanity." Brown adds, "It was the beastly and most of all the sexual part of his humanity that Joyce felt the Church most excluded ... " (Brown 1985, pp. 15-16). In the phrase "the impulses of my nature" we can sense Joyce's early interest in instinct and his awareness that instinct posed a problem for Catholic thinking, since it implies an uncomfortable link between the human and the animal.

In Joyce's education "reason" and "instinct" appear as opposing terms, with cognition, reason, or knowledge referring to those mental processes based purely in the mind, while instinct designates a faculty "lower" than thought, something based in our bodies—the "animal" part of our nature. As Lisa Osbeck has observed, the word instinct derives from the Latin instinguerre ("to instigate, incite, impel," according to the Oxford English Dictionary). She suggests that "Stoic epistemology ... distinguishes the faculty of reason from a lower, impulsive tendency, generated by the body." She concludes, "Given its bodily origin, instinct appears to be consistently contrasted with reason prior to the seventeenth century" (Osbeck 2005, p. 185). Gary Steiner notes that for Thomas Aquinas, animals "do not act but are rather acted upon" (Steiner 2005, p. 128). As Steiner explains Aquinas' sense of the "imperfect volition"" of animals, "Animals are bound to the future not by cognition, as in the case of humans, but instead are "moved by natural instinct [ex instinctu naturali movetur]"' (Steiner 2005, p. 128). Steiner explains that "Aquinas develops his conception of experience in animals under the influence of Aristotle. Human beings are rational and possess freedom, whereas animals are imprisoned in the particulars of sense experience" (Steiner 2005, p. 127); accordingly, "Aquinas says that the functioning of 'brute animals cannot occur apart from the body"' (Steiner 2005, p. 130).

Maud Ellmann suggests that "Joyce's interest in the murky division between man and animal reaches back to his Paris notebooks of 1904, where he makes careful notes on Aristotle's theory of the animals" (Ellmann 2006, p. 77), but he clearly encountered this Aristotelian view, filtered through Thomas Aquinas and other Catholic thinkers, as early as his time studying at Belvedere College between 1893 and 1898. The most important source we have for Joyce's early thinking on the relationship between animals and humans is Michael Maher's book Psychology (Maher n.d.), a volume in Joyce's Trieste Library penned by a Jesuit priest and annotated in Joyce's handwriting. Based on the style of annotation, Michael Patrick Gillespie suggests that this was one of Joyce's textbooks at Belvedere College (Gillespie 1986, pp. 158-59). Maher's book clearly articulates the Catholic view of instinct as a "lower," animalistic faculty lodged in the body (in contrast to the "higher" faculty of reason). Throughout the book, Maher struggles to defend traditional Catholic ideas based in Aristotle and Aquinas against what he calls "the Atheistic Materialistic school" (Maher n.d., p. 540) of evolutionary biologists, represented by Charles Darwin and Thomas Henry Huxley, among others. Maher's religious view of the nature of the human being and the human body is presented in contrast to what he calls "empiricism" or materialism. "If all mental operations are of a sensuous organic nature," he writes, "then evidently there is no reason for asserting that the soul of man is a spiritual principle of an order superior to that of the brute. The method of the empiricist is, on the one hand, to depreciate the value of those peculiar characteristics which mark off our intellectual acts, and, on the other, to exaggerate the capabilities of sense" (Maher n.d., p. 258).

Maher connects instinct in animals to the idea of "locomotion" (Maher n.d., pp. 218-22). Instinct is the force that impels the animal to move toward pleasure or away from pain. If animals have no reason, soul, or free will, then following Aquinas, Maher concludes the animal must always by definition be "moved" or "acted upon" in some sense. While Maher acknowledges some instinctual behaviors in human psychology (especially in infants), he goes to great pains to warn about the shortcomings of "comparative psychology," stressing the differences between humans and "the various species of the brute kingdom" (Maher n.d., p. 546) ("brute" is a word Maher uses frequently as a synonym for animals, as when he writes, "the possession of reason is said to separate man from the brute" (Maher n.d., p. 233, fn. 4)). For Maher, then, instinct is a faculty possessed primarily by animals, who 
have no reason and no souls and are therefore trapped in their bodies. On the other hand, human beings, in his view, have souls and therefore are generally not subject to instinct, or at least not after infancy. This idea is most fully demonstrated by the fact that his only sustained discussion of "instinct" occurs in the final four pages of his book, in a "Supplementary Chapter" entitled "Animal Psychology." Here we learn that "Instinct may perhaps be best defined as a natural aptitude which guides animals in the unreflecting performance of complex acts useful for the preservation of the individual or of the species" (Maher n.d., p. 555; original emphasis). Quoting from Henri Milne-Edwards' book Zoologie, Maher explicitly contrasts "instinctive actions from those that may be called intelligent or rational," concluding with Milne-Edwards that "Reason supposes a judgment and a choice: instinct, on the contrary, is a blind impulse which naturally impels the animal to act in a determinate manner: its effects may sometimes be modified by experience, but they never depend on it." For Maher, this proves "that animal 'intelligence' is different, not in degree, but in kind from human intellect" (Maher n.d., pp. 555-56; original emphasis). Not surprisingly, he attributes the fundamental difference to the human soul, arguing that "The brute manifests no spiritual activity. It is not endowed with rational intellect nor, consequently, with free-will. In other words, all the mental actions exhibited by it are of the lower or sensuous order, and therefore intrinsically or essentially dependent on a material organism" (Maher n.d., p. 557). To be an animal, then, is to be merely a body lacking the cogito that defines humanity.

We can see these Catholic attitudes toward the animal body reflected in one of the earliest non-fiction pieces we have from Joyce's hand: the untitled fragment of an 1898 essay on "Force" or "Subjugation"2 written as "a part of Joyce's matriculation course at university" (Joyce 2000, p. 290). Here Joyce views the body and instinct-indeed, nature itself-as something to be subdued, in keeping with the views of Catholic psychologists like Maher. In this academic essay, Joyce considers the positive and negative ramifications of "subjugation" in human social relations and relations with animals. He writes that after Adam's fall, "the beasts of the field" revolted and became "bitter foes to him," but "at length by superior power and because he was man and they were but brutes, they, at least to a great extent, were overcome" (Joyce 2000, p. 5). Joyce goes on to praise "this desire of man to overcome," which "not merely destroys and conquers the worse features but betters and improves what is good" (Joyce 2000, pp. 8-9). In the end, he writes, "'the power of the regenerate human soul"' will bring about

The wished subjugation that must come in good time. And meanwhile we have considered the power of overcoming man, against the lower races of the world, and his influence in the subjugation of his own mental faculties, and there remains for us to consider the manifold influence of his desire to conquer, over his human instincts, over his work and business and over his reason. (Joyce 2000, pp. 8-9)

Similarly, in his essay "Drama and Life," written in 1900, Joyce argues that drama arises from "mere animal instinct applied to the mind" (Joyce 2000, p. 26).

As I noted earlier, Maher was concerned about the effects that "empiricism" and Darwinian thinking would have on Catholic schoolboys like James Joyce, and Joyce clearly learned about Darwin and evolutionary theory during his early years in Dublin. Many writers, including John Gordon (Gordon 2003), Paul Bowers (Bowers 1999), Dirk van Hulle (van Hulle 2009), Scarlett Baron (Baron 2013), and Sandra Tropp (Tropp 2008), have explored Joyce's engagement with Darwin in particular and with evolutionary theory more generally. Tropp, in particular, has remarked upon Darwin's presence in A Portrait, focusing especially on Stephen Dedalus' aesthetic theory, which she claims is "suffused with allusions to Darwinian science, beginning with the perception of man's animal nature" (Tropp 2008, p. 226). More generally, she notes,

2 In The Critical Writings of James Joyce (1959), the essay is given the title "Force," while Kevin Barry's more recent volume, James Joyce: Occasional, Critical, and Political Writing, uses the title "Subjugation." 
a number of characters are identified with animals, from Brother Michael, who "had a long back like the long back of a tramhorse" (Joyce 1968a, p. 23), to the dean of studies with "his aging body, spare and sinewy, greyed with a silverpointed down," resting on his "hunkers" and watching sticks catch fire like some furred ancestral man (Joyce 1968a, p. 185), to Cranly's labeling of Pascal and Aloysius Gonzaga as pigs (Joyce 1968a, p. 242). In the aesthetic discussion in which the reference to Origin of Species takes place, Lynch laughs like an elephant, and his skull reminds Stephen "of a hooded reptile" (Joyce 1968a, pp. 209, 201, 205).

(Tropp 2008, p. 226)

Although Joyce had a copy of Thomas Henry Huxley's Twelve Lectures and Essays in his Trieste library (Gillespie 1986, p. 124), we do not know for certain how much of Darwin's writing he read. ${ }^{3}$ It is clear, however, that he was familiar with Friedrich Nietzsche's works early in his writing career. ${ }^{4}$ Of all the materialist authors writing in Darwin's wake, Marx and Nietzsche were the most influential and the most forceful. We know that Joyce was familiar with Nietzsche's writing by the time he wrote Dubliners, since Mr. Duffy, in "A Painful Case," has "on his shelves ... two volumes by Nietzsche: Thus Spake Zarathustra and The Gay Science" (Joyce 1968b, p. 112). Joyce's brother Stanislaus wrote, "Jim had also lent Mr. Duffy some traits of his own, the interest in Nietzsche and the translation of Michael Kramer, in order to raise his international standard" (Joyce 1958, p. 160). Instinct is a constant if complex theme in Nietzsche's writings and often stands in contrast to a kind of sterile spirituality or rationality. As Walter Kaufmann explains it, Nietzsche views instinct as necessary for us to attain "a state of perfect mastery" through "what one might call an attained unconsciousness" (Kaufmann 1974, p. 233).

Nietzsche ties instinct to human animality and contrasts his embrace of the body with what he sees as Christianity's revulsion from it. In a remarkable passage in The Genealogy of Morals, Nietzsche rejects the conventional religious morality that turned away from the body and hence from instinct, railing against

the morbid softening and moralization through which the animal "man" finally learns to be ashamed of all his instincts. On his way to becoming an "angel" (to employ no uglier word) man has evolved that queasy stomach and coated tongue through which not only the joy and innocence of the animal but life itself has become repugnant to him-so that he sometimes holds his nose in his own presence and, with Pope Innocent the Third, disapprovingly catalogues his own repellent aspects ("impure begetting, disgusting means of nutrition in his mother's womb, baseness of the matter out of which man evolves, hideous stink, secretion of saliva, urine, and filth"). (Nietzsche 1989, p. 67)

Nietzsche views the unfortunate human who has undergone "a forceful sundering from his animal past, ... a declaration of war against the old instincts" as an "animal that rubbed itself raw against the bars of its cage as one tried to 'tame' it; this deprived creature, racked with homesickness for the wild, who had to turn himself into an adventure, a torture chamber, an uncertain and dangerous wilderness-this fool, this yearning and desperate prisoner became the inventor of 'bad conscience'" (Nietzsche 1989, p. 85).

The Gay Science develops a similar perspective on instinct. Here Nietzsche conceives of the instinct of "the herd" as a negative form of instinct developed from the pressure of habitual "moral" behavior, a view that we will see suits Joyce's portrayal of "instinct" in Dubliners. "Morality," Nietzsche writes, "trains the individual to be a function of the herd and to ascribe value to himself only as a function ...

3 Based on Stephen's aesthetic discussion with Lynch in A Portrait of the Artist as a Young Man, Sandra Tropp assumes that Joyce was familiar with On the Origin of Species and The Descent of Man (Tropp 2008, p. 223).

4 Sam Slote's book Joyce's Nietzschean Ethics (Slote 2013) provides a useful overview of Joyce's engagement with Nietzsche's thought, although his focus on Joyce's response to Nietzsche primarily "as a theorist of style" takes him in a different direction than my own. 
Morality is the herd instinct in the individual" (Nietzsche 1974, pp. 174-75). Nietzsche again assails the "slanderers of nature" who have curtailed instinct:

I find those people disagreeable in whom every natural inclination immediately becomes a sickness, something that disfigures them or is downright infamous: it is they that have seduced us to hold that man's inclinations and instincts are evil. They are the cause of our great injustice against our nature, against all nature. (Nietzsche 1974, p. 236)

Finally, a more fundamental sense of instinct as unconscious cognition that surpasses the value of conscious thought emerges in The Gay Science when Nietzsche writes, "For the longest time, conscious thought was considered thought itself. Only now does the truth dawn on us that by far the greatest part of our spirit's activity remains unconscious and unfelt" (Nietzsche 1974, p. 262).

The human animals we encounter in Dubliners seem to correspond to Michael Maher's view of instinct as a mechanistic, animal faculty associated with the body and disconnected from rational thought. As Joyce explained in his correspondence, he wanted Dubliners "to betray the soul of that hemiplegia or paralysis which many consider a city" (Joyce 1957-1966, I, p. 55), and "instinct" becomes one of the paralyzing forces that retard the development of Joyce's characters in the book. Oddly, while we might be accustomed to thinking of "instinct" as an internal force that motivates the organism to preserve itself-often by acting or moving - in Dubliners "instinct" seems often to contribute to a deadly stasis and paralysis, rather than movement or "locomotion." Like Nietzsche's herd animals, torn from their animal natures, Joyce's Dubliners seem unable to free themselves from the psychological cages in which they are imprisoned.

Instincts in Dubliners often stop characters in their tracks. In Dubliners, instinct provides no path out of Dublin's labyrinth but only leads to more paralysis. In this early work, Dubliners are often represented as animalistic in the older and more negative sense put forth by Aquinas and developed by Maher. In "Eveline," for example, the main character is reduced to the level of a "mere animal," just as the preceding story, "Araby," ends with the humiliated narrator viewing himself "as a creature driven and derided by vanity" (Joyce 1968b, p. 35). While "vanity" is not a trait we normally associate with animals, the narrator's conclusion that his confusion reduced him to the status of a "creature driven" by outside forces is similar to Maher's views. When we first meet Eveline, we learn that when she was a child her "father used often to hunt" her and her siblings "out of the field" where they were playing (Joyce 1968b, p. 36). As Eveline struggles internally with her decision-whether to stay at home with her abusive father or to leave for "Buenos Ayres" with her "lover" Frank-instinct seems to provide no guidance. At one point, she is violently impelled to leave Dublin when she remembers the "final craziness" of her mother's death. This troubling memory affects her instinctively, and "She stood up in a sudden impulse of terror. Escape! She must escape!" (Joyce 1968b, p. 40). Here, memory and self-preservation seem to work together to impel her to flee, and Eveline instinctively decides to join Frank at the docks.

Following Eveline's impulsive rush to the docks, however, a competing impulse takes hold-her fear of change. One could argue that both of these instincts-the panicked urge to flee her cage-like home and the terrified paralysis that keeps her from moving "beyond the barrier" with Frank—could be valid; the story does not really give us sufficient information to know which course is right. Nevertheless, at the story's end we see Eveline reduced to the state of one of Father Maher's instinctive brutes-"passive, like a helpless animal." She prays to God "out of a maze of distress," but the maze is too much for her, and like Nietzsche's "animal that rubbed itself raw against the bars of its cage," Eveline grasps "with both hands at the iron railing" as Frank tries to pull her away. The final sentence- "Her eyes gave him no sign of love or farewell or recognition"-emphasizes her similarity to a "dumb animal" or "brute" (Joyce 1968b, pp. 40-41). In "Eveline," we see a Dubliner reduced to animal status despite-or perhaps even because of-her animal instincts. Eveline is portrayed as not sufficiently human at the end of the story to choose what is best for her, nor do her instincts help her preserve herself. 
Another Dubliners story in which instinct plays an important role is "The Boarding House," which contains more direct references to "instinct" than any other Dubliners story. In this story, Bob Doran, a meek Dublin clerk, collides with Mrs. Mooney, the "butcher's daughter," who possesses a ferocious drive for self-preservation. In this story, Mrs. Mooney works in unspoken collusion with her daughter Polly to ensnare Mr. Doran, apparently the only boarder tame enough to fall into their trap. Here, Bob Doran's course, like Eveline's, leads him into a morass of conflicting and paralyzing forces. Seduced by Polly, he finds himself in Mrs. Mooney's clutches. Doran's status as social livestock may be implied in the ominous phrase "She dealt with moral problems as a cleaver deals with meat" (Joyce 1968b, p. 63), referring to her decision to arraign him for his misbehavior with Polly. Mrs. Mooney, with "all the weight of social opinion on her side," glances "instinctively at the little gilt clock on the mantelpiece" (Joyce 1968b, p. 64) as she prepares to force him into marrying her daughter. Despite the seeming inevitability of his fate, Doran feels "the instinct of the celibate" warning him "to hold back" (Joyce 1968b, p. 67): "His instinct urged him to remain free, not to marry" (Joyce 1968b, p. 66). Nonetheless, the story's ending finds him "going down the stairs" to meet Mrs. Mooney. As he descends the stairs, Doran "longed to ascend through the roof and fly away to another country where he would never hear again of his trouble, and yet a force pushed him downstairs step by step" (Joyce 1968b, pp. 67-68). The narrator turns again to Polly at the end, as she rests "the nape of her neck against the cool iron bed-rail" and falls into a "revery" (Joyce 1968b, p. 68). The bed here becomes another cage or trap; its iron bed-rail parallels the "iron railing" that Eveline grasps so desperately at the docks. We may have trouble sorting out the various impulses or instincts that affect Mr. Doran here: sexual desire, habitual celibacy, propriety, guilt, and-not least-physical fear of Polly's boxer brother Jack, with his "thick bulldog face" (Joyce 1968b, p. 68). Like Eveline, he is unable to preserve himself or to fly away as he wishes to and finds his instincts useless in the face of stronger, paralyzing forces. In Dubliners, human beings often resemble animals as Maher describes them-body-bound victims of powerful forces, unable to think clearly or make rational decisions, trapped and paralyzed in Joyce's Dublin.

One final and instructive example of animality as a sign of paralysis occurs in "The Dead." While Gabriel Conroy may at first seem more cosmopolitan or knowing than Eveline or Bob Doran, he is also at times "a creature driven and derided by vanity," and near the end of the story we find him telling a humorous story about his grandfather's horse Johnny to the guests preparing to leave the party. As he tells the story of an animal so befuddled and paralyzed by habit that he cannot behave instinctively and break free when given the chance, Gabriel unconsciously mimics Johnny's paralyzed circling around King Billy's statue:

Gabriel paced in a circle round the hall in his goloshes amid the laughter of the others.

"Round and round he went," said Gabriel, "and the old gentleman, who was a very pompous old gentleman, was highly indignant. 'Go on, sir! What do you mean, sir? Johnny! Johnny! Most extraordinary conduct! Can't understand the horse!" (Joyce 1968b, pp. 207-8)

These references to "instinct" and animality consistently link animality and paralysis; "instinct" in Dubliners does not work as a locomotive force, but functions instead to underscore the characters' paralysis and similarity to animals. I do not mean to suggest that in Dubliners Joyce endorses attitudes about animals and the body that he found in Aristotle, Aquinas, and Maher and then left behind. Instead, he uses "instinct" and animal imagery to support the theme of paralysis in this collection. However, a change begins to take place after Dubliners, and in Stephen Hero and A Portrait of the Artist as a Young Man, we see a more active, overt critique of the Catholic denigration of the body in contrast to the soul and a developing portrayal of the body as a source of knowledge or cognition, accompanied by a corresponding change in Joyce's use of animal imagery. As we witness a gradual change in representations of the body and of animals, we can begin to trace a movement away from the often helpless and degraded human animals of Dubliners toward a portrayal of liberation through the animal body and its instincts. 
In Stephen Hero, Joyce uses the term "instinct" ambiguously to refer both to physical impulses and to social habits. For example, in thinking about Jesus as a figure of veneration, Stephen considers that

... his enfranchisement from the discipline of the Church seemed to be coincident with an [natural] instinctive return to the Founder thereof and this impulse would have led him perhaps to a consideration of the merits of Protestantism had not another natural impulse inclined him to bring even the self-contradictory and the absurd into order. (Joyce 1963, p. 112)

It is difficult to know what the deleted word "natural" might signify here, in connection with "instinctive" and "impulse," when the behavior under examination seems more subtle and more cerebral than "instinct." At one point, Stephen even conceives of the Church itself as having a "certain amoeboid instinct" in the "expansion and contraction" that enables it to engulf and incorporate "external" ideas (Joyce 1963, p. 123). Soon after, Stephen considers "the legend of the mild heresiarch of Assisi" and we learn that he "knew, by instinct, that S. Francis' love-chains would not hold him very long" (Joyce 1963, p. 176). Instinct seems to have little consistent meaning here, and its connection to cognition or knowing seems more related to mental inclinations than to the body as a source of knowledge. Nonetheless, in a striking passage reminiscent of Nietzsche's attacks on the "slanderers of nature" quoted above, Stephen ponders the relationship between Catholicism, the body, and instinct or "natural impulse":

In a stupor of powerlessness he reviewed the plague of Catholicism. He seemed to see the vermin begotten in the catacombs in an age of sickness and cruelty issuing forth upon the plains and mountains of Europe ... Contempt of [the body] human nature, weakness, nervous tremblings, fear of day and joy, distrust of man and life, hemiplegia of the will, beset the body burdened and disaffected in its members by its black tyrannous lice. Exultation of the mind before joyful beauty, exultation of the body in free confederate labours, every natural impulse towards health and wisdom and happiness had been corroded by the pest of these vermin. The spectacle of the world in thrall filled him with the fire of courage. (Joyce 1963, p. 194)

Stephen's thoughts here echo Nietzsche's critique, in On the Genealogy of Morals, of those who practice "conscience-vivisection and self-torture," wedding "natural inclinations" to "bad conscience," exalting instead "all those aspirations to the beyond, to that which runs counter to sense, instinct, nature, animal, in short all ideals hitherto, which are one and all hostile to life and ideals that slander the world" (Nietzsche 1989, p. 95).

In A Portrait of the Artist as a Young Man we witness the most startling and transformative changes in Joyce's views of the human/animal body. In this novel, Stephen Dedalus moves from fear and loathing of the animality of his body to a transitional and tentative embrace of instinct. Here we begin to see the development of the role that animal instinct might play in breaking through the "bad conscience" created by "Catholic psychology." While A Portrait is a book of advances and retreats, at key moments in the text Stephen's body seems unconsciously to move him out of confusion. At Clongowes, Stephen believes that "By thinking of things you could understand them" (Joyce 1968a, p. 43), and yet his understandings are often muddled or incomplete. Time after time, Stephen finds that thinking fails to lead him out of the traps he wanders into, from Wells' question "do you kiss your mother before you go to bed?" (Joyce 1968a, p. 14), to the inconsistent, hesitant responses he makes to "the constant voices" he hears around him, urging him to take one path or another in life. His "mind" pursues these "intangible phantoms" (Joyce 1968a, p. 83), but in the end his body proves a better guide.

At first, however, Stephen's body's animality causes him problems in A Portrait. Readers easily see that Stephen is alternately drawn to and repelled by his body and its urges, overwhelmed by his senses and desires and then impelled to repress and mortify his body in vain attempts to rid himself 
of his sexual impulses or instincts. Steeped in a culture and religion that has taught him that the animal body is suspect and dangerous, Stephen views his adolescent sexual feelings as "brutish" and "monstrous reveries" that "sweep across and abase his intellect"; he wonders "where they came from, from what den of monstrous images" (Joyce 1968a, p. 90). Michael Nunn notes that "Stephen's sexual abasings are attended by a cast of animals, who are predictable both in their presence and in their species ... Goats, apes, 'brutes' in general-these are predictable, traditional symbols for the drives we ascribe to animals as a way of cleansing ourselves" (Nunn 2009, p. 145).

By the second chapter of the novel, Stephen has come to fear his own body's urges and instincts, since he is maturing into his own sexuality without any guidance. Stephen tries to rely on rationality but nonetheless must cope with a body that often baffles and disgusts him. As he begins to feel sexual desire he comes to see his body as a threat to his soul and begins to oscillate hysterically between the two. In the middle three chapters of the novel, Stephen's relationship with his own flesh is figured primarily through animal images, and most if not all of these are frightening or disgusting. He imagines "the hell reserved for his sins: stinking, bestial, malignant, a hell of lecherous goatish fiends" (Joyce 1968a, p. 138). In other tortured passages, Stephen thinks of himself as a "baffled prowling beast" (Joyce 1968a, p. 99) that "prowled in quest" of the prostitutes' "sudden call to his sinloving soul from their soft perfumed flesh" (Joyce 1968a, p. 102). Instinct or desire, disgust, and animality mingle with "flesh" to tantalize and terrify him.

Stephen does try to orient himself toward the body in Chapter II, when he finally gives in to his "monstrous urges" and descends into the dark maze of Dublin's prostitution district. Even here, however-at the end of Chapter II and the start of Chapter III-the impression we derive from the text is that his thinking is still fully boxed in by what Joyce sees as the Roman Catholic view of the animal body and its urges-bestial and deeply troubling. The "transfiguration" he desires from his sexual encounter with the body of another person-here, the prostitute-is not forthcoming in part because his sexual choices are constrained by a society that consigns poor women to selling their bodies while it simultaneously idealizes femininity in the form of the Virgin Mary. His sexual initiation occurs fully within the paradigm set up by the Church, in which the body and its animal urges drag any element of "mind" or "spirit" into Hell along with it.

The word "instinct" first appears in A Portrait in Father Arnall's sermons. First, he explains, "Evil company on earth is so noxious that the plants, as if by instinct, withdraw from the company of whatsoever is deadly or hurtful to them" (Joyce 1968a, p. 122). The priest tells the boys that to sin is "to yield to the promptings of your lower nature, to live like the beasts of the field, nay worse than the beasts of the field for they, at least, are but brutes and have no reason to guide them" (Joyce 1968a, pp. 123-34). He goes on to remind them that
"Sin ... is a twofold enormity. It is a base consent to the promptings of our corrupt nature to the lower instincts, to that which is gross and beast-like; and it is also a turning away from the counsel of our higher nature, from all that is pure and holy, from the Holy God Himself. For this reason mortal sin is punished in hell by two different forms of punishment, physical and spiritual." (Joyce 1968a, p. 127)

In his Psychology, Maher introduces instinct in his chapter on "Sensuous Appetite and Locomotion," considering it part of "a tendency in all sentient beings to seek pleasure and shrink from pain in any form" (Maher n.d., p. 218). A careful reading of the prepositions in Father Arnall's brief meditation on sin above reveals an abundance of "to's" and "from's." Sin, then, is a movement towards the animal and away from that part of us that should be closest to God (that part of us farthest from the animal).

Father Arnall takes care to describe the torments of Hell vividly, using all five senses to argue against the lures of the body. Father Arnall's discourses on Hell terrify Stephen, and they are full of physical and sensual detail, dwelling on the sights, sounds, smells, tastes, and tactile sensations experienced by the damned. We also notice in an ironic passage that the priest's "face was kind and he joined gently the fingers of each hand forming a frail cage by the union of their tips" (Joyce 1968a, p. 127; my emphasis). 
Stephen learns that his senses and his animal instincts will lead him to damnation, and yet the reader should see that this view of the flesh is a trap. Stephen's terrorized response to Father Arnall's sermons manifests itself in a tumbling series of animal images, as when he thinks "So he had sunk to the state of a beast that licks his chaps after meat," or when he fantasizes that "the body that was his stood, listless and dishonoured, gazing out of darkened eyes, helpless, perturbed and human for a bovine god to stare upon" (Joyce 1968a, p. 111). Here, the fading boundary line between animal and human has become a threat to Stephen's identity, and the imagery recalls the endings of "Araby" and "Eveline" in its evocation of the animal body as a passive and helpless "thing." This alienation from the body is especially evident when he considers his own sinful death and imagines, "He, himself, his body to which he had yielded was dying. Into the grave with it! Nail it down into a wooden box, the corpse ... Thrust it out of men's sight into a long hole in the ground, into the grave, to rot, to feed the mass of its creeping worms and to be devoured by scuttling plumpbellied rats" (Joyce 1968a, p. 112). The body is now a nonhuman thing to be "devoured" and incorporated into the bodies of vile animals.

Stephen's problems stem primarily from his guilt about his sexual desires and "sinful" encounters. At one point, he considers the temptation of lust and views his penis as a source of instinctive desire and as an "animal" separate from himself:

Then in an instant it happens. But does that part of the body understand or what? The serpent, the most subtle beast of the field. It must understand when it desires in one instant and then prolongs its own desire instant after instant, sinfully. It feels and understands and desires. What a horrible thing! Who made it to be like that, a bestial part of the body able to understand bestially and desire bestially? Was that then he or an inhuman thing moved by a lower soul? His soul sickened at the thought of a torpid snaky life feeding itself out of the tender marrow of his life and fattening upon the slime of lust. (Joyce 1968a, pp. 139-40)

In this remarkable passage, Joyce demonstrates the way in which fear and loathing of the body as a thing separate from and inferior to the soul create a sense of panic in Stephen. Michael Nunn summarizes the progress and process of Stephen's thinking here:

The first stage is, predictably, to label the desire as animal: "serpent," "beast." The second stage involves acknowledging that, though bestial, it is "a bestial part of the body": it has yet to be thoroughly denied and exteriorized. Stage three is to question the situation in stage two, to wonder whether "it" is, in fact, part's [sic] of one's human being: "Was that then he or an inhuman thing moved by a lower soul than his soul?" Stage four involves final divestiture: Desire and person are given separate identities, separate existences, separate lives: The "torpid snaky life" (life number one) feeds on the "tender marrow of his life" (life number two). Stephen has moved the troubling interior animal to the exterior (in Freud's terms, he has made it wild, unheimlich). (Nunn 2009, pp. 146-47)

O'Connor argues that here we see Stephen struggling "to extricate an authentic 'self' from the mire of the lustful, sensual body, the 'inhuman' animal envelope of the soul" (O'Connor 2013, p. 107). The phrase "an inhuman thing moved by a lower soul" is especially telling, in its connection of instinctual motivation and a lack of humanity; here, bestial instinct is perceived as separate from mind and full humanity - a form of knowing that is pre-conscious or unconscious and therefore repulsive and frightening. At first, Joyce's portrait of the artist as a young animal is a portrait of helplessness and disgust in response to the realities of an animal body Stephen cannot fully accept or deny.

In $A$ Portrait we can see Stephen move wildly in one direction and then another-away from the body and its "promptings" and toward the Church and the possibility of a clerical vocation, and then away from the Church and toward what he considers to be a more sensuous, embodied life as "a priest of [the] eternal imagination, transmuting the daily bread of experience into the radiant body of everliving life" (Joyce 1968a, p. 221). In these twists and turns, and in his locomotion toward and 
away from various sources of pleasure and pain, Stephen gradually begins to listen to what his body tells him. Instinct plays a key role in his transformation.

As we have seen, the lectures on hell in the third chapter of the novel quickly bring Stephen to heel, halting for a time his indulgence of his body and his sexuality. Father Arnall is the same priest who stood by years before at Clongowes while Stephen was unfairly beaten by Father Dolan, which—along with the cage he makes with his fingers as he speaks-alerts the reader to the trap Stephen is about to fall into. Nonetheless, following Arnall's sermons and Stephen's subsequent confession, we see Stephen motivated once more towards the Church and towards "amended" behaviors based on attempts to repress the body and mortify the senses.

A crucial change in the novel occurs in the fourth chapter, however, when Stephen meets the director, the priest who asks him "'Have you ever felt that you had a vocation?'” (Joyce 1968a, p. 157). Joyce sets the scene with a subtle but menacing image as "The director stood in the embrasure of the window, his back to the light, leaning an elbow on the brown crossblind, and, as he spoke and smiled, slowly dangling and looping the cord of the other blind" (Joyce 1968a, pp. 153-54). This quick succession of linked images- "his back to the light," the "crossblind," and the implication of a noose formed from the "cord of the other blind," followed by the image of "the curves of the skull" that ends the paragraph - provides us with another suggestion of entrapment, blindness, and death. When the priest enters the room where Stephen awaits him, Stephen hears "the handle of the door turning and the swish of a soutane" (Joyce 1968a, p. 154; my emphasis), an echo of the phrase that Joyce uses in the first chapter when Stephen feels Father Dolan touch his hand "to straighten it" and then hears "the swish of the sleeve of the soutane as the pandybat was lifted to strike" (Joyce 1968a, p. 50).

Although Stephen is initially wooed by the director's description of the "awful power" (Joyce 1968a, p. 158) of the priesthood, as he leaves the priest and begins to imagine himself as a priest, his body and his instinct take over. Involuntarily, he recollects "The troubling odour of the long corridors of Clongowes," and "At once from every part of his being unrest began to irradiate ... His lungs dilated and sank as if he were inhaling a warm moist unsustaining air and he smelt again the warm moist air which hung in the bath in Clongowes above the sluggish turfcoloured water." Suddenly, "Some instinct, waking at these memories, stronger than education or piety, quickened within him at every near approach to that life, an instinct subtle and hostile, and armed him against acquiescence. The chill and order of the life repelled him" (Joyce 1968a, pp. 160-61; my emphasis). Here, Stephen's body, stimulated by involuntary memory and the sense of smell, relives the assaults on his body at his first school. He panics and instinct takes over-here, a locomotive instinct of flight. Accordingly, when Stephen speaks to the Dean of Studies in the final chapter of the novel and hears the "hard jingling tone" of the priest's voice, "Stephen's mind [is] halted by instinct," as he imagines that behind the priest's face lies "a dull torpor of the soul" (Joyce 1968a, pp. 187-88), a phrase that earlier in the novel might have been more closely associated with the body rather than the soul.

Shortly after his refusal of a priestly vocation, Stephen ponders his motives for the decision: "All through his boyhood he had mused upon that which he had so often thought to be his destiny and when the moment had come for him to obey the call he had turned aside, obeying a wayward instinct. Now time lay between: the oils of ordination would never anoint his body. He had refused. Why?" (Joyce 1968a, p. 165). Here, Joyce models a kind of somatic cognition-an instinctive decision-making based upon bodily promptings; Stephen's instinct here seems "wayward" to himself, but the reader can justifiably read it as not wayward at all, but rather an advantageous instinctive impulse arising from his body, partly veiled from consciousness and rationality. Arguably, one of the most important moments in the novel-when Stephen decides not to become a priest—is stimulated almost entirely by instinct and the body, rather than reflection, rationality, or the "soul." Here, at this crucial moment in the novel, Stephen discovers the body as a way of knowing, an unconscious unity of world and perception, of memory and instinct, that proves to be a better guide than Stephen's self-conscious "intellection."

As A Portrait proceeds towards its conclusion, Stephen increasingly embraces the body as a way of knowing that is central to his art. This process is not simple or straightforward, however, and Joyce 
allows the "chaosmic" back and forth movement we have seen throughout the novel to continue to the end of the text. For example, in the final chapter, Stephen transfers the Catholic suspicion of instinct and the flesh into his aesthetic theory in order to move back into a more familiar way of thinking, seeking to avoid the demands of the body. When Stephen outlines his aesthetic ideas for Lynch, they seem designed to paralyze the body, to proscribe art that is "kinetic." At one point he tells Lynch, "we are all animals. I also am an animal," and yet he turns immediately away from the animal when he moves to explain his aesthetic theory, saying, "But we are just now in a mental world." Stephen continues by denigrating "the flesh" as a source of artistic inspiration:

The desire and loathing excited by improper esthetic means are really unesthetic emotions not only because they are kinetic in character but also because they are not more than physical. Our flesh shrinks from what it dreads and responds to the stimulus of what it desires by a purely reflex action of the nervous system. Our eyelid closes before we are aware that the fly is about to enter our eye.

-Not always, said Lynch critically.

-In the same way, said Stephen, your flesh responded to the stimulus of a naked statue, but it was, I say, simply a reflex action of the nerves. Beauty expressed by the artist cannot awaken in us an emotion which is kinetic or a sensation which is purely physical. It awakens, or ought to awaken, or induces, or ought to induce, an esthetic stasis ... (Joyce 1968a, p. 206)

Stephen here argues against instinct ("simply a reflex action of the nerves") and against what Father Maher might call the instinctive locomotion or kinesis of the animal body, instead hoping that his ideal art can cordon off the body and its instincts through an ideal stasis. Tellingly, however, when Stephen creates his own work of art in the form of a villanelle in the final chapter of the novel, it is full of sexual longing and hence "kinetic" - the body begins to reassert itself in the push-pull of competing forces that constitutes the dynamic of $A$ Portrait.

The presence of Lynch as Stephen's interlocutor in this scene serves as a foil to Stephen's focus on stasis and "beauty" separate from the flesh. Both $\mathrm{O}^{\prime}$ Connor and Nunn have commented upon Lynch's function here, with the former arguing "Lynch's intimate ease with the 'lowliness' of the body, with sex and excrement, contrasts with Stephen's discomfort with his own body, his 'animal' self" ( $\mathrm{O}^{\prime}$ Connor 2013, p. 106) and the latter claiming "Lynch mocks Stephen by speaking Animal in the gaps of Stephen's theory; he restores what Stephen has removed" (Nunn 2009, p. 123).

Nunn goes on to assert that "Stephen's world of art is unreal because partial; he has simply opted out of a large part of human experience, which he deems low because physical-because, ultimately, animal" (Nunn 2009, p. 142). Garry Leonard develops this point by connecting Father Arnall's sermon with Stephen's aesthetic theory, viewing the latter as a canny representation on Joyce's part of the ways in which the type of Catholic psychology he encountered in Maher's book saturates Stephen's psyche at every level, making him into what Leonard calls "a pleasure anorexic" and engendering "an orgy of punitive self-surveillance, one in which he systematically tries to destroy his senses as pleasure receptors" (Leonard 1998, p. 182). Stephen's aesthetic theory is then a movement backward or retreat, an attempt to reconstruct the Catholic abhorrence of the body and its desires in a secular sphere. However, we can presume by this point in the novel that Stephen's intense regime of self-surveillance and self-control will not last, and as A Portrait moves towards its conclusion perhaps the most important change in Stephen is his explicit embrace of his body and-for the first time-his connection of his art to his body. Stephen is still too much the idealist-he still thinks too much-and at the end of the book he still lives at too much of a remove from his body, as his aesthetic theory demonstrates; in fact, references to "the soul" seem to increase, rather than decrease, in the final chapter. However, as Stephen leaves the director, having been propelled by his "instinct subtle and hostile" away from the priesthood and its distrust of the body, he notices "The faint sour stink of rotted cabbages" coming "towards him from the kitchen gardens on the rising ground above the river. He smiled to think that it was this disorder, 
the misrule and confusion of his father's house and the stagnation of vegetable life, which was to win the day in his soul" (Joyce 1968a, p. 162). Here, the body and the physical world-represented primarily through the sense of smell-seem to triumph. Earlier in the novel, as Michael Nunn has noted (Nunn 2009, p. 147), Stephen tends to associate smell with his own loathing of the body-for example, "The sordid details of his orgies stank under his very nostrils" (Joyce 1968a, p. 115) and "God had allowed him to see the hell reserved for his sins: stinking, bestial, malignant, a hell of lecherous goatish fiends" (Joyce 1968a, p. 138). Now, however, following his instinctive movement away from the Church in response to the "troubling odour of the long corridors of Clongowes" in the fourth chapter, Stephen's reaction to the odor of decay seems to point to a way forward. Contrasting a reference to "the Cartesian spring" in Finnegans Wake to Stephen's aesthetic theory in A Portrait, Eugene O'Brien suggests that "despite Stephen's initial swerve towards the intellectualisation of the apprehension of beauty ... Joyce's more developed aesthetic theory is, in fact, a deconstruction of the mind/body duality, and acts as a call for the primacy of bodily sensations in the aesthetic as a whole" (O'Brien 2014, p. 201).

As the novel moves toward its end, we can best observe Stephen's ambivalence concerning the human body and its animal nature in his differing responses to two women: the "bird-girl" he encounters on the beach at the end of Chapter IV and the "bat-woman" who enters his imagination in Chapter V when Davin tells a story about meeting a peasant woman who appears to be pregnant and who invites him to spend the night with her. Central to the final two chapters are two women, both represented as embodied human beings and creatures of air and flight, in contrast to the dull and frightening goats, cows, and snakes that inhabit the earlier chapters of the novel.

In the fourth chapter, Stephen encounters "A girl ... alone and still, gazing out to sea. She seemed like one whom magic had changed into the likeness of a strange and beautiful seabird." Stephen sees this young woman in the guise of an animal and seemingly as a creature of flesh and blood: "Her long slender bare legs were delicate as a crane's and pure save where an emerald trail of seaweed had fashioned itself as a sign upon the flesh. Her thighs, fuller and softhued as ivory, were bared almost to the hips ... " (Joyce 1968a, p. 171). Yet he also apprehends the bird-girl through the lens of his idealism; despite his awareness of her bared thighs and her "flesh," he abstracts her into a "wild angel ... an envoy from the fair courts of life" (Joyce 1968a, p. 172), while keeping her safely at a distance. To emphasize her stasis, the text twice describes her as "alone and still" - key attributes of the beautiful in Stephen's aesthetic theory. Stephen never speaks to her, and she remains for him an "image" that "had passed into his soul forever," an "angel of mortal youth and beauty," akin in some ways to the "image" of Mangan's sister the narrator of "Araby" carries like a "chalice" (Joyce 1968b, p. 31) - a self-serving idea rather than a person. Stephen's description of her is tinged with religious terms-an angel, subject to "the worship of his eyes" who exists primarily to stimulate "the holy silence of his ecstasy" (Joyce 1968a, pp. 171-72). The blending of flesh and world (flesh, seaweed, and animal) in this passage full of chiasmic phrasing-exists in tension with Stephen's tendency to privilege "soul" over flesh and an ideal image over the presence of an actual human being. Although Stephen has convinced himself that "the misrule and confusion of his father's house and the stagnation of vegetable life ... was to win the day in his soul" (Joyce 1968a, p. 162), he remains hesitant to commit himself to his body or "flesh"; his embrace of the body, while couched here in positively-charged animal terms, is still ambivalent. O'Connor agrees, noting that Stephen's encounter with "the 'bird girl' on the shore suggests a revelation of the desires of mind and body as inextricably bound up in each other" ( $\mathrm{O}^{\prime}$ Connor 2013, p. 107), but at the same time, "While animal nature is not slimy and depraved here, neither is it successfully integrated into the human. The girl's human lineaments are buried under rapidly accumulating metaphors ... " (O'Connor 2013, p. 108).

While Stephen never recalls this encounter throughout the rest of the novel (or in Ulysses, for that matter), the bat-woman, in contrast, haunts his thoughts. Immediately after Davin first tells him about meeting this woman ("The last words of Davin's story sang in his memory"), Stephen converts her into "a type of her race and his own, a batlike soul waking to the consciousness of itself in darkness 
and secrecy and loneliness" (Joyce 1968a, p. 183), and this image recurs in the text at key moments (Stephen always genders the soul—even his own—as female). For example, Stephen considers whether Emma may hide "the secret of her race ... behind those dark eyes," thinking "bitterly as he walked through the streets that she was a figure of the womanhood of her country, a batlike soul waking to the consciousness of itself in darkness and secrecy and loneliness" (Joyce 1968a, p. 221). And just before he encounters Cranly at the end of the novel, he feels the

thoughts and desires of the race to which he belonged flitting like bats across the dark country lanes, under trees by the edges of streams and near the pool-mottled bogs. A woman had waited in the doorway as Davin had passed by at night and, offering him a cup of milk, had all but wooed him to her bed; for Davin had the mild eyes of one who could be secret. But him no woman's eyes had wooed. (Joyce 1968a, p. 238)

That the bat-woman takes a more prominent place in Stephen's imagination than the bird-girl is an important sign that, while Stephen has not simply lost his distrust of the body, his awakening to instinct and somatic awareness following his interview with the director has freed him to move toward an appreciation of the sexual and desiring nature of the body by the end of the book. In a continuing oscillation between soul and body, he equates both women with the soul, but the bat-woman, in contrast to the virginal bird-girl, becomes an image of body and soul commingled, a sign of artistic generation coupled with sexual reproduction and instinct. Cranly, in his final conversation with Stephen, reminds him, "Whatever else is unsure in this stinking dunghill of a world a mother's love is not. Your mother brings you into the world, carries you first in her body. What do we know about what she feels? But whatever she feels, it, at least, must be real. It must be" (Joyce 1968a, pp. 241-42). In Cranly's words we can hear a connection to the bat-woman-pregnant and active in Stephen's imagination, in contrast to static image of the bird-girl—and a hint of what Stephen's mother may mean when she tells him that he needs to learn "what the heart is and what it feels" (Joyce 1968a, p. 252).

Although Stephen is still very much a work in progress at the end of the novel, we see in A Portrait the beginnings of a movement towards a greater acceptance of the body and its instinctive urges, a desire for movement and flight, and a liberation of the human animal. This movement complicates and undermines what Joyce came to see as a distrust or loathing for the body and opens the door for Joyce's fuller embrace of animals, the human body, and instinct in Ulysses and Finnegans Wake. In Dubliners and A Portrait, Joyce creates a portrait of the human animal alienated from its own physicality, disgusted by its own flesh, and finally freed to an extent by an awakening brought about by the body and its instincts. In Joyce's early prose, the body is transformed from an impediment to an essential locus for human agency, cognition, and identity. The evolution of instinct from a mechanical behavior that appears to block the characters of Dubliners, at times reducing them to helpless animals, to a dynamic and productive force in A Portrait of the Artist as a Young Man, prepares the way for Joyce's "epic of the human body," in which Leopold Bloom feels free to think, "Instinct rules the world. In life. In death" (Joyce 1986, p. 421). The animal—once so separate and frightening—becomes us.

Conflicts of Interest: The author declares no conflict of interest.

\section{References}

Baron, Scarlett. 2013. Joyce, Darwin and Literary Evolution. In James Joyce in the Nineteenth Century. Edited by John Nash. New York: Cambridge University Press, pp. 183-99.

Bowers, Paul. 1999. Variability in Every Tongue': Joyce and the Darwinian Narrative. James Joyce Quarterly 36: 869-88.

Brown, Richard. 1985. James Joyce and Sexuality. Cambridge: Cambridge University Press.

Budgen, Frank. 1972. James Joyce and the Making of 'Ulysses' and Other Writings. Oxford: Oxford University Press.

Eco, Umberto. 1982. The Aesthetics of Chaosmos: The Middle Ages of James Joyce. Translated by Ellen Esrock. Tulsa: University of Oklahoma Press.

Ellmann, Maud. 2006. Ulysses: Changing into an Animal. Field Day Review 2: 74-93. 
Gillespie, Michael Patrick. 1986. James Joyce's Trieste Library: A Catalogue of Materials at the Harry Ransom Humanities Research Center, The University of Texas at Austin. Austin: Harry Ransom Humanities Research Center.

Gordon, John. 2003. Physiology and the Literary Imagination: Romantic to Modern. Gainesville: University Press of Florida.

Haraway, Donna. 1991. A Cyborg Manifesto: Science, Technology, and Socialist-Feminism in the Late Twentieth Century. In Simians, Cyborgs, and Women: The Reinvention of Nature. New York: Routledge, pp. 149-81.

Joyce, James. 1957-1966. Letters. 3 vols, Edited by Stuart Gilbert and Richard Ellmann. New York: Viking.

Joyce, Stanislaus. 1958. My Brother's Keeper: James Joyce's Early Years. New York: Viking.

Joyce, James. 1963. Stephen Hero, new ed. Edited by Theodore Spencer. New York: New Directions.

Joyce, James. 1968a. A Portrait of the Artist as a Young Man: Text, Criticism, and Notes. Edited by Chester G. Anderson. New York: Viking Press.

Joyce, James. 1968b. Dubliners. New York: Penguin.

Joyce, James. 1986. 'Ulysses': A Critical and Synoptic Edition. Edited by Hans Walter Gabler, Wolfhard Steppe and Claus Melchior. New York: Random House.

Joyce, James. 2000. Occasional, Critical, and Political Writing. Edited by Kevin Barry. Oxford: Oxford University Press.

Kaufmann, Walter. 1974. Nietzsche: Philosopher, Psychologist, Antichrist, 4th ed. Princeton: Princeton University Press.

Leonard, Garry. 1998. Advertising and Commodity Culture in Joyce. Gainesville: University Press of Florida.

Maher, Michael. n.d.; Psychology, 2nd ed. Manuals of Catholic Psychology; New York: Benziger Brothers.

Nietzsche, Friedrich. 1974. The Gay Science: With a Prelude in Rhymes and an Appendix of Songs. Translated by Walter Kaufmann. New York: Vintage.

Nietzsche, Friedrich. 1989. On the Genealogy of Morals/Ecce Homo. Translated by Walter Kaufmann. New York: Vintage.

Norris, Margot. 2014. The Animals of James Joyce's Finnegans Wake. MFS Modern Fiction Studies 60: 527-43. [CrossRef]

Nunn, Michael Russell. 2009. James Joyce's Animal Aesthetic. Ph.D dissertation, University of Virginia, Charlottesville, VA, USA.

O'Brien, Eugene. 2014. 'Can excrement be art if not, why not?' Joyce's Aesthetic Theory and the Flux of Consciousness. In Eco-Joyce: The Environmental Imagination of James Joyce. Edited by Robert Brazeau and Derek Gladwin. Cork: Cork University Press, pp. 197-212.

O'Connor, Maureen. 2013. “Mrkgnao!": Signifying Animals in the Fiction of James Joyce. In James Joyce. Edited by Albert Wachtel. Ipswich: Salem Press, pp. 101-19.

Osbeck, Lisa. 2005. Instinct, 'Primitive' Cognition, and the Transformation of Intuition. Passauer Schriften zur Psychologiegeschichte 13: 184-92. [PubMed]

Plock, Vike Martina. 2014. Bodies. In The Cambridge Companion to 'Ulysses'. Edited by Sean Latham. New York: Cambridge University Press, pp. 184-99.

Rando, David. 2009. The Cat's Meow: Ulysses, Animals, and the Veterinary Gaze. James Joyce Quarterly 46: 529-43. [CrossRef]

Rickard, John S. 1998. Joyce's Book of Memory: The Mnemotechnic of 'Ulysses'. Durham: Duke University Press.

Schaefer, Donovan O. 2016. Heavenbeast: A new materialist approach to Ulysses. Angelaki 21: 119-37. [CrossRef] Slote, Sam. 2013. Joyce's Nietzschean Ethics. New York: Palgrave Macmillan.

Steiner, Gary. 2005. Anthropocentrism and Its Discontents: The Moral Status of Animals in the History of Western Philosophy. Pittsburgh: University of Pittsburgh Press.

Tropp, Sandra. 2008. 'The Esthetic Instinct in Action': Charles Darwin and Mental Science in A Portrait of the Artist as a Young Man. James Joyce Quarterly 45: 221-44. [CrossRef]

van Hulle, Dirk. 2009. Paper Fossils: Joyce's 'Origin of Spices' and the Imperfections of the Archival Record. Dublin James Joyce Journal 2: 95-105. [CrossRef]

(C) 2017 by the author. Licensee MDPI, Basel, Switzerland. This article is an open access article distributed under the terms and conditions of the Creative Commons Attribution (CC BY) license (http:/ / creativecommons.org/licenses/by/4.0/). 